\title{
Clinical trials face lack of minority group volunteers
}

Washington. The US National Cancer Institute (NCI) was urged last week to host a 'summit' conference to consider ways of improving the recruitment of individuals from minority groups to clinical trials.

At a meeting of the National Cancer Advisory Board last week, Zora Brown, a board member and patient advocate, said that the need for such a conference was demonstrated by the fact that deaths from breast cancer are not declining among African American women as they are among white women.

Breast cancer is one of many diseases that cause more deaths among minorities than among the white population. Researchers and patient advocates agree that understanding differences in disease requires the recruitment to clinical trials of representative numbers of minorities. Yet minorities are at present underrepresented in all but treatment trials.

During the past few years, the National Institutes of Health (NIH) have become increasingly aware of the general issue, drawing up guidelines in 1986 for the inclusion of women and minorities in clinical trials.

More recently, the NIH Revitalization Act specified in 1993 that: women, minorities and subpopulations be included in research, that women and minorities be included in phase three clinical trials so that differences in response to drugs can be examined; that cost is not an acceptable reason for exclusion; and that programmes must be established to recruit and keep women and minorities in clinical research and trials.

\section{Satellite failure hits Japan's space plans}

Tokyo. Japan's Institute of Space and Astronautical Science (ISAS) suffered a rare setback last weekend (15/16 January) when a joint mission with Germany to launch a small Russian-made re-entry vehicle crashed back to Earth shortly after take-off. The failure may delay Japan's plans for an unmanned shuttle.

The 'Express' capsule, with a cone constructed by the Krunichev space centre in Moscow, was supposed to enter orbit and then return to Earth six days later in the Australian desert. The two stages of the solid-fuel M-3SII launch vehicle provided by ISAS fired successfully. But the capsule did not enter its correct orbit, and is believed to have crashed in the Pacific Ocean a few hours after its launch from ISAS's Kagoshima space centre.
Since June 1994, the NIH has had guidelines in place in response to the act, and researchers not recruiting adequate numbers of women or minorities are now liable to lose their grants.

But putting the guidelines into practice is proving difficult for a variety of reasons. One is distrust. Among African Americans in particular, this stems from trials such as one begun in Tuskegee, Alabama, in the 1930s in which African American men were recruited so that researchers could observe the prevalence and progress of syphilis. When treatment became available, the men were not told, but observations continued.

Barbara Howard, a physician in Washington DC who has worked with Native Americans and African Americans, says that even though people may not be able to say specifically why they distrust research, there is a kind of 'folklore' stemming from events such as those at Tuskegee.

Another researcher with experience in the recruitment of minorities is Otis Brawley from the NCI. He makes a distinction along educational lines, and points out that a lot of minorities are in blue-collar jobs, "making it from paycheck to paycheck. They have a lot of other things to think about without taking time from work to sit in a doctor's office."

Often, too, members of a local community do not see how the research will help them. According to Howard, researchers in an organization moving into a community looking for study subjects usually have few ties to the community and little understanding of local difficulties. One government official says that this problem is widespread, and particularly obvious now that researchers must fulfil quotas.

It is most significantly a factor in trials designed to consider behavioural and environmental factors influencing disease. A simple example, says Howard, is that if one is interviewing someone about diet one will get a more honest response if the interviewers are from the community rather than $\mathrm{PhDs}$ from the research organizations.

Howard's approach is endorsed by others who have worked with minority populations. But Sandra Millon Underwood, an associate professor in the nursing department at the University of Wisconsin, Milwaukee, says that she has heard reports of researchers reluctant to employ investigators from backgrounds similar to those of the study population for fear that their background will affect their observations.

Underwood is also concerned that in their efforts to fulfil quotas, researchers may recruit subjects who will receive only marginal benefit from participation.

Helen Gavaghan
Falling stock prices put the squeeze on biotech start-ups

San Francisco. Venture capital's enthusiasm for funding start-up bioscience companies has been dampened by a dismal year for the US biotechnology industry, according to industry leaders attending a conference organized by the stockbrokers Hambrecht \& Quist in San Francisco last week.

Last year, 86 per cent of biotechnology stocks fell in value. The financial squeeze on small companies is forcing them to cut spending and look for partnerships that can bring immediate revenue.

As returns fall on the creation of such companies, venture capitalists - who traditionally invest in individuals bringing new ideas into the business arena - are concentrating on maintaining their current portfolios and on capitalizing on existing collaborations with universities.

Stephen Evans-Freke, chairman and chief executive of Sugen Inc., a Californian biotechnology company specializing in cancer research, says that the low prices of many biotech-nology stocks "make it difficult to justify all the heartache [involved] in a startup". He and others told last week's meeting that although venture capitalists will continue to fund new companies, this will be at a slower pace than before, and university researchers will need an outstanding technology in order to persuade investors to back a new venture.

One problem has been the proliferation of companies carrying out mediocre work, according Timothy Wilson, senior biotechnology analyst for Hambrecht \& Quist. Only about one-seventh of the 230 or so companies in the biotechnology industry are excellent at what they do, Wilson said. "There are still too many half companies, too many bad companies; too much pride, too much hype," he said.

Dennis Purcell, managing director of lifesciences investment banking for Hambrecht \& Quist, said that venture capitalists are likely in future to invest more in fewer companies, and to stay with them longer. Companies short of money and unable to raise new capital are prioritizing their research and cutting back on new projects, often resulting in fewer research jobs.

Wilson said there is still demand for good companies able to develop practical applications of the genetics revolution. But many companies are now likely to start up with smaller infrastructure than in the past, or in collaboration with other groups that would formerly have operated independently.

Futhermore, highly speculative work is likely to find it more difficult than in the past to raise financial support, as venture capitalists select projects that have already proved their worth.
Sally Lehrman 